\title{
Brazilian Protocol for Sexually Transmitted infections 2020: approaching sexually active individuals
}

\author{
Maria Alix Leite Araujo ${ }^{[1],}$ Juliana Uesono ${ }^{[2]}$ Nádia Maria da Silva Machado ${ }^{[2],}$ \\ Valdir Monteiro Pinto ${ }^{[3],[4]}$ and Eliana Amaral[5]
}

[1]. Universidade de Fortaleza (UNIFOR), Programa de Pós-Graduação em Saúde Coletiva, Fortaleza, CE, Brasil

[2]. Ministério da Saúde, Secretaria de Vigilância em Saúde, Brasília, DF, Brasil

[3]. Secretaria do Estado da Saúde de São Paulo, CRT-IST/Aids, Programa Estadual de IST/Aids, São Paulo, SP, Brasil.

[4]. Secretaria Municipal da Saúde, Coordenação Municipal de IST/Aids, São Paulo, SP. Brasil.

[5]. Universidade Estadual de Campinas, Faculdade de Ciências Médicas, Campinas, SP, Brasil

\begin{abstract}
This article aims to present concepts and clinical practices recommended to approach people with active sex life. These concepts are an integral part of the recommendations of the Clinical Protocol and Therapeutic Guidelines for Comprehensive Care for People with Sexually Transmitted Infections (STI), published by the Ministry of Health of Brazil in 2020. The article proposes a comprehensive approach to sexuality for health promotion. It presents significant aspects of the communication process that must develop, without prejudice and judgment, focusing on sexual and reproductive health. It also highlights relevant points about the exercise of sexuality at specific stages of life, recommending assessment of risks and vulnerabilities and screening for STI and condom use. In this way, it is possible to contribute to exercise their sexuality fully, responsibly, and safely.
\end{abstract}

Keywords: Sexuality. Sexually transmitted infections. Disease prevention. Diagnosis screening programs. Clinical protocols. Surveillance.

Highlighted excerpt: Sexual health is the physical, emotional, mental, and social wellbeing associated with the exercise of sexuality, with sexual and reproductive rights considered fundamental.

\section{FOREWORD}

This article aims at updating the chapter on Sexual Health: an approach centered on sexually active individuals of the Clinical Protocol and Therapeutical Guidelines (PDCT) for Comprehensive Care for People with Sexually Transmitted Infections (STI) $2020^{1}$. We highlight the main thematic points: the communication in approaching sexual health, sexuality in specific life stages, assessment of risks and vulnerabilities, STI tracing, and condom use. We made adaptations in the chapter items to make it more adequate regarding issues of other STIs different from HIV, as it has a specific clinical protocol' ${ }^{2}$.

\footnotetext{
Corresponding author: Maria Alix Leite Araujo.

e-mail: mleite@unifor.br

(D) https://orcid.org/0000-0002-4156-5783

Received 01 February 2021

Accepted 10 March 2021
}

The PDCT was published by the Health Surveillance Department of the Brazilian Ministry of Health, based on official recommendations and discussions with experts. The National Committee approved it for Technology Incorporation to the Unified Health System (Conitec) in 20183. It proposes a sensitive approach to sexuality, aiming at improving the health of sexually active individuals.

\section{INTRODUCTION}

Sexual and reproductive rights are considered fundamental, together with the rights to life, food, health, housing, and education for the complete exercise of citizenship ${ }^{4}$. The right of individuals and couples of all sexual orientations to have their sexual health preserved is recognized. Sexual health is defined as the physical, emotional, mental, and social wellbeing associated with the exercise of sexuality and not just the lack of sexual infections, disorders, or diseases $^{5}$. It is considered an essential component for promoting human development ${ }^{6}$. It implies the exercise of safe and healthy sexual experiences without coercion, discrimination, or violence? Finally, sex is understood as one of the essential dimensions of sexuality, not limited to genitality or reproduction ${ }^{8}$. 


\section{COMMUNICATION IN THE APPROACH TO SEXUAL HEALTH}

The communication process plays a significant role in the improvement of the professional-patient relationship and, as a consequence, for the adherence to the recommendations and treatment ${ }^{9}$. Health professionals can be unprepared and feel embarrassed when it comes to approaching patients regarding STI and sexuality ${ }^{10}$. The offer of adequate training could minimize such embarrassment and contribute to qualifying such professionals' performance, aiming to make them familiar with the different concepts of gender, sexual orientation, and identity.

Health services must promote environments favorable to the dialog and embrace the different dimensions of the exercise of sexuality by sexually active individuals. We recommend a gradual approach, advancing from general aspects to the most specific ones ${ }^{11}$. Adequate approach to sexuality must encompass guidelines on prevention and identification of risk factors and vulnerabilities, sexual practices, and behaviors that favor STI contamination.

To establish an association of trust, we need a clear and transparent approach, adequate to receptivity and the life context of the persons, which must be recognized as active individuals in the care process ${ }^{10}$. All services must favor the development of autonomy of the subjects for identifying solutions to their demands. The approach must take place free from prejudiced attitudes, labels, and stigmatization, understanding sexuality as part of the culture and the historical, social, and life context of each individual ${ }^{4}$.

We recommend to the professional to assure that the person is comfortable to talk about such themes, informing them that those are questions made routinely in the healthcare service, regardless of sex, sexual orientation, age, professional activity, and marital status. Emphasis should be placed on the secrecy and confidentiality of information ${ }^{12,13}$ General guidelines on communication can be found in Figure 1.

Telemedicine has currently been gaining ground in disclosing information, promotion and prevention, expanding the scope of healthcare services, especially in a continental country with regions that are hard to reach. Useful communication techniques in servicing people with STI are also needed in telemedicine ${ }^{14}$. For this reason, it is necessary to incorporate its use in the service to people with STI, respecting the ethical limits and current recommendations regarding data storage, handling and transmission, as well as confidentiality, privacy and the guarantee of professional secrecy ${ }^{15}$.

\section{SEXUALITY IN SPECIFIC LIFE STAGES}

Adolescence is a period of significant biological, psychological and social transformations. Physical alterations, social interactions and the awakening of new interests reflect fast and profound changes that characterize this life stage. The way adolescents express and live sexuality is influenced by the quality of emotional and affective associations experienced with relevant people in childhood, integration with peers, transformation arising from growth and development, the start of reproductive capacity, beliefs, moral patterns, myths, and taboos, as well as the traditions of the family or society in which they are inserted ${ }^{16}$.

In this stage, values, attitudes, habits, and behaviors are being formed, transformed, and consolidated, making adolescents more vulnerable, mainly because parents or guardians, school, and even health staff tend not to approach the aspects regarding the exercise of sexuality. Therefore, many times adolescents start their sexual lives without due orientation ${ }^{17}$.

Healthcare services can play a fundamental role, disclosing to adolescents information contributing to the awakening of a healthy sexual life and prevention of STI and unintended pregnancy. Such orientation must be based on dialog, allowing for autonomy and responsible attitudes ${ }^{18}$. The approach must comply with confidentiality and privacy principles, indispensable for trust and respect between adolescents and health professionals ${ }^{19}$. It also must take place from the point of view of comprehensive care, providing access to different technologies associated with combined prevention ${ }^{16}$.

During gestation, sexual relations do not pose a risk to pregnancy, except in unique obstetric situations (membrane rupture, cervical

Guidelines for approach to sexuality by healthcare staff

Set a routine of questions to all users on sexuality (dialog on sex and sexual practices).

Develop your style, observing a respectful association.

Avoid previous judgments. Do not assume preconceived notions (unless you ask, there is no way of knowing someone's sexual orientation, behaviors, practices or gender identity).

Respect the patient's limits (non-verbal language). Observe for any discomfort and reformulate the questions or briefly explain why you are making this questions, in case the patient seems offended or reluctant in answering.

Monitor and restrain your reactions (non-verbal languages).

Say the same questions are made to everyone (protocol procedure), regardless of sex, age, profession or marital status.

Use neutral and inclusive terms (for example, "partner" instead of "boyfriend", "girlfriend", "husband", or "wife") and make questions in a non-judgmental way.

When servicing a transexual person, ask how they want to be called or identified. Offer support to the current gender identity, even if the anatomy does not correspond to such exactness.

FIGURE 1: General guidelines for approach to sexuality by healthcare staff. 
insufficiency, short cervix, or premature delivery). However, we should not ignore the possibility of a pregnant woman getting an STI that harms the gestation's prognosis, or vertically transmitting the disease. For this reason, healthcare staff must approach routine questions associated with the sexual health of pregnant women and their sexual partners and offer HIV, syphilis, and hepatitis B and C tests in prenatal care ${ }^{18}$.

Older adults presented an increase in the number of HIV and syphilis cases over the last years, drawing attention to the role of sexuality in this age group ${ }^{20,21}$. There are essential aspects that increase vulnerability, as lower genital lubrication in women, and male erection difficulty ${ }^{20-22}$. Besides, it is a generation that was not sexually initiated with safe sex.

\section{RISK ASSESSMENT, VULNERABILITIES, AND STI TRACING}

In risk assessment for STI in sexually active individuals, we recommend investigating structured questions, identifying factors associated with sexual practices and behaviors, and alcohol and drug use. From the contents obtained, it is possible to make an adequate assessment for risk management and identify opportunities for recommending preventive actions. The professional must individually provide the attendance, and in a private environment ${ }^{1,16,23}$. Figure 2 presents questions for the attendance towards risk assessment.

Risk assessment can guide STI tracing. After identifying clinical cases, it is crucial to call and treat the sexual partnerships,

\section{Suggestions for questions to be made by healthcare staff to sexually active people}

\begin{tabular}{|c|c|}
\hline Sexual health & $\begin{array}{l}\text { "I am going to ask some questions on sexual health. As sexual health is important for general health, I always } \\
\text { question patients on that. If it is all right for you, I will ask some questions on sexual matters now. Before } \\
\text { starting, ask if the person have any questions or concerns regarding your sexual health that would like to } \\
\text { discuss?" }\end{array}$ \\
\hline \multirow{3}{*}{ Identification } & $\begin{array}{l}\text { "How do you consider yourself (sexual orientation)? Homosexual (gay, lesbian), heterosexual, bisexual, other, } \\
\text { do you not know?" }\end{array}$ \\
\hline & "What is your gender identity? Men, women, transexual men, transexual woman, transvestite, other?" \\
\hline & "With which sex were you designated when born, how are you registered in your birth certificate?" \\
\hline \multirow{5}{*}{ Partners } & "Have you ever had sexual relations?" \\
\hline & $\begin{array}{l}\text { If so: "How many sexual partners did you have last year?" (or another period, according to clinical examination } \\
\text { to be carried out in medical appointment). }\end{array}$ \\
\hline & "Did you have sexual relations with men, women or both?" \\
\hline & $\begin{array}{l}\text { "Over the last three months, did you have sexual relations with somebody you did not know or had just } \\
\text { known?" }\end{array}$ \\
\hline & "Have ever been forced or pressed to have sexual relations?" \\
\hline \multirow{3}{*}{ Sexual practices } & $\begin{array}{l}\text { "Over the last three months, what kinds of sex did you have? Anal? Vaginal? Oral? Receptive (bottom), } \\
\text { penetrative (top), both (bottom and top)?" }\end{array}$ \\
\hline & "Did you or your partner use alcohol or drugs when having sex?" \\
\hline & "Have you ever exchanged sex for drugs or money?" \\
\hline \multirow{2}{*}{ History of sexually transmitted infections } & $\begin{array}{l}\text { "Have you ever had a sexually transmitted infection?" If so: "Which? Where was the infection? When was it? } \\
\text { Did you treat it? Did your partner get treated?" }\end{array}$ \\
\hline & $\begin{array}{l}\text { "Have you ever being tested for HIV, syphilis, hepatitis B/C?" If so: "How long ago did this test happen? What } \\
\text { was the result?" }\end{array}$ \\
\hline \multirow{3}{*}{ Protection } & "What do you do to protect yourself from sexually transmitted infections, including HIV?" \\
\hline & "When do you use protection? With which partners?" \\
\hline & "Have you been vaccinated for hepatitis B? Hepatitis A? HPV?" \\
\hline \multirow{3}{*}{ Family planning } & "Do you wish to have (other) children?" \\
\hline & $\begin{array}{l}\text { If so: "How many children would you like to have? When would you like to have a child? What are you and } \\
\text { your partner doing to prevent pregnancy by now?" }\end{array}$ \\
\hline & $\begin{array}{l}\text { If no: "Are you doing something to prevent pregnancy?" (Make sure to make the same questions for } \\
\text { transsexual people that still have female reproductive organs). }\end{array}$ \\
\hline
\end{tabular}

Source: adapted from Rocha et al., 201910; Nusbaum, Hamilton, 2002 30 ; Workowski, Bolan, $2015^{31}$.

FIGURE 2: Routine service questions for assessment of the risk of sexually transmitted infections. 
aiming to interrupt the chain of infection, prevent complications, and avoid reinfections ${ }^{1}$. In Brazil, the PDCT recommends screening asymptomatic subgroups ${ }^{1}$ to identify and treat infected individuals earlier, looking to prevent STI dissemination and their complications ${ }^{24}$.

European guidelines recommend managing sexual partners of people with STI, indicating emotional support and contact identification and notification, through a strategy guided by pattern operational procedure for control, monitoring, treatment, and report of cases ${ }^{25}$.
Brazil presents a trend of HIV and syphilis increase in the population between 13 and 29 years of age ${ }^{20,21}$. For this reason, it recommends the annual tracing of such infections in people up to 30 years old who are sexually active. Other diseases are screened depending on population groups and sexual practices that expose people to more significant risks. Figure 3 presents recommendations for tracing people in any age group.

It is important to trace some infections, such as chlamydia and gonococcus, aiming at preventing pelvic inflammatory disease that,

\begin{tabular}{|c|c|c|c|c|}
\hline \multirow{2}{*}{ Subgroups } & \multicolumn{4}{|c|}{ Frequency } \\
\hline & HIV & Syphilis $^{b}$ & $\begin{array}{l}\text { Chlamydia and } \\
\text { gonococcus }\end{array}$ & Hepatitis $B^{d}$ and $C^{e}$ \\
\hline Adolescents, young people & \multicolumn{2}{|c|}{ Annually } & \multicolumn{2}{|c|}{$\begin{array}{l}\text { Frequency as per other population subgroups or sexual } \\
\text { practices below }\end{array}$} \\
\hline Pregnant women & \multicolumn{2}{|c|}{$\begin{array}{l}\text { - In the first prenatal care appointment (ideally, in the } 1^{\text {st }} \\
\text { trimester); } \\
\text { - At the start of the } 3^{\text {rd }} \text { trimester }\left(28^{\text {th }} \text { week); }\right. \\
\text { - At the moment of delivery, regardless of previous } \\
\text { examinations. } \\
\text { In case of miscarriage/stillbirth, test for syphilis, regardless of } \\
\text { previous examinations. }\end{array}$} & $\begin{array}{l}\text { In the first prenatal care } \\
\text { appointment (for pregnant } \\
\text { women } \leq 30 \text { years) }\end{array}$ & $\begin{array}{c}\text { Hepatitis B: in the first } \\
\text { prenatal care appointment } \\
\text { (ideally, in the } 1^{\text {st }} \text { trimester) } \\
\text { Hepatitis C: in the first } \\
\text { prenatal care appointment }\end{array}$ \\
\hline $\begin{array}{l}\text { Gays and men that have sex } \\
\text { with other men }\end{array}$ & \multirow{4}{*}{\multicolumn{2}{|c|}{ Biannually }} & \multirow{4}{*}{$\begin{array}{l}\text { Check frequency as per other } \\
\text { population subgroups or } \\
\text { sexual practices }\end{array}$} & \multirow{4}{*}{ Biannually } \\
\hline Sex workers & & & & \\
\hline $\begin{array}{l}\text { Transvestites/transsexual } \\
\text { people }\end{array}$ & & & & \\
\hline $\begin{array}{l}\text { People using alcohol and } \\
\text { other drugs }\end{array}$ & & & & \\
\hline $\begin{array}{l}\text { People with a diagnosis of } \\
\text { sexually transmitted infections }\end{array}$ & \multicolumn{2}{|c|}{$\begin{array}{l}\text { At the moment of diagnosis and } 4 \text { to } 6 \text { weeks from the } \\
\text { diagnosis of sexually transmitted infections }\end{array}$} & At the moment of diagnosis & At the moment of diagnosis \\
\hline $\begin{array}{l}\text { People with viral hepatitis } \\
\text { diagnosis }\end{array}$ & At the moment of diagnosis & - & - & - \\
\hline $\begin{array}{l}\text { People with tuberculosis } \\
\text { diagnosis }\end{array}$ & At the moment of diagnosis & - & - & - \\
\hline People living with HIV & & Biannually & At the moment of diagnosis & Annually \\
\hline $\begin{array}{l}\text { People with receptive } \\
\text { (bottom) unprotected anal } \\
\text { sexual practice }\end{array}$ & \multicolumn{4}{|c|}{ Biannually } \\
\hline Prisoners & Annually & Biannually & - & Biannually \\
\hline Sexual violence & $\begin{array}{l}\text { At initial service; } 4 \text { to } 6 \text { weeks } \\
\text { after exposure and three } \\
\text { months after exposure }\end{array}$ & \multicolumn{2}{|c|}{ At initial service and 4 to 6 weeks after exposure } & $\begin{array}{l}\text { At initial service and } 3 \text { to } 6 \\
\text { months after exposure }\end{array}$ \\
\hline $\begin{array}{l}\text { People using pre-exposure } \\
\text { prophylaxis for HIV infection } \\
\text { risk (PrEP) }\end{array}$ & In each visit to the service & Quarterly & Biannually & Quarterly \\
\hline $\begin{array}{l}\text { People indicating post- } \\
\text { exposure prophylaxis for HIV } \\
\text { infection risk (PEP) }\end{array}$ & $\begin{array}{l}\text { At initial service; } 4 \text { to } 6 \text { weeks } \\
\text { after exposure and three } \\
\text { months after exposure }\end{array}$ & $\begin{array}{l}\text { At initial service and } 4 \text { to } 6 \\
\text { weeks after exposure }\end{array}$ & $\begin{array}{l}\text { At initial service and } 4 \text { to } 6 \\
\text { weeks after exposure (except } \\
\text { in cases of an accident with } \\
\text { biological material) }\end{array}$ & $\begin{array}{l}\text { At initial service and six } \\
\text { months after exposure }\end{array}$ \\
\hline
\end{tabular}

a) HIV: preferably with a rapid test; b) Syphilis: preferably with a rapid test; c) Chlamydia and gonococcus: chlamydia and gonococcal detection through molecular biology. Research according to sexual practice: urine (urethral), endocervix samples, genital secretion. For extragenital samples (anal and pharyngeal ones), use tests to validate such anatomic collection sites; d) Hepatitis B: preferably with a rapid test. We recommend vaccinating everyone susceptible to hepatitis B. Susceptible person is the one who does not have a record of a complete vaccine scheme and presents non-reacting surface antigen for hepatitis $B$ virus (or nonreacting rapid test for hepatitis $\mathrm{B}$ ); e) Hepatitis $\mathrm{C}$ : preferably with a rapid test; f) If the pregnant woman has not carried out tracing in prenatal care, perform a rapid test for hepatitis B at the moment of delivery. Hepatitis B vaccine is safe during pregnancy, and susceptible women must be vaccinated.

FIGURE 3: Tracing indication for sexually transmitted infections according to population subgroups. 
even if asymptomatic, can reduce chances of pregnancy ${ }^{26}$. In Brazil, screening for chlamydia infections is recommended for pregnant women younger than 30 years old due to the high prevalence of infection in this age group ${ }^{27}$.

Figure 3 presents recommendations for tracing STI according to population subgroups, as proposed by the PDCT for Comprehensive Care for People with STI $2020^{1}$.

\section{CONDOM USE}

Using female, or male condoms is a preventive strategy that should be offered to sexually active people, in order to reduce the risk of HIV and other STI transmission and prevent pregnancy ${ }^{28}$. Despite the low adherence and acceptance of the female condom, it is deemed necessary in situations where it is difficult for the women to negotiate the use of the male condom ${ }^{29}$.
The offer of condoms must take place without the quantity restrictions and without requiring identification documents. Figure 4 presents the guidelines for conservation and correct use of male and female condoms. They should be part of the healthcare staff's approach in all services, especially highly vulnerable individuals.

\section{CONCLUDING REMARKS}

Healthcare professionals must incorporate sexuality into services to sexually active individuals, mainly those with STI complaints. This approach must develop, without prejudice and judgment, with a focus on sexual and reproductive health. In this way, it is possible to contribute to exercise their sexuality fully, responsibly, and safely. The right preventive approach can favor the decrease of STIs and their consequences.

\begin{tabular}{|c|c|c|}
\hline Care with latex male condom & Care with female latex condom & $\begin{array}{l}\text { Factors contributing to rupture or leakage of } \\
\text { male condom }\end{array}$ \\
\hline $\begin{array}{l}\text { Store it away from heat, observing package } \\
\text { integrity, as well as best before date. }\end{array}$ & $\begin{array}{l}\text { Store it away from heat, observing package } \\
\text { integrity, as well as best before date. }\end{array}$ & Poor storage conditions. \\
\hline $\begin{array}{l}\text { It must be placed before penetration, during penis } \\
\text { erection. }\end{array}$ & Do not use it together with a male condom. & Non-compliance with best before date. \\
\hline $\begin{array}{l}\text { Press the edge of the condom between your } \\
\text { fingers while placing it, taking all air inside. }\end{array}$ & $\begin{array}{l}\text { The female can be placed even before the } \\
\text { relationship and taken out freely after intercourse, } \\
\text { preferably before the women get up, to avoid } \\
\text { sperm drips from inside the condom. }\end{array}$ & Package damage. \\
\hline $\begin{array}{l}\text { Still holding the condom edge, unroll it to the base } \\
\text { of the penis. }\end{array}$ & $\begin{array}{l}\text { The female condom is already lubricated; then, } \\
\text { there is no need for lubricants. }\end{array}$ & Insufficient vaginal lubrication. \\
\hline $\begin{array}{l}\text { Use water-based lubricants (lubricating gel). The } \\
\text { lubricating gel makes anal sex easier and reduces } \\
\text { the chances of the lesion. }\end{array}$ & $\begin{array}{l}\text { To put it correctly, the woman must find a } \\
\text { comfortable position (standing up with one foot } \\
\text { on a chair, sit with knees apart, squatting or lying } \\
\text { down). }\end{array}$ & $\begin{array}{l}\text { Use of oily lubricants, such as vaseline or food oil. } \\
\text { Anal sex without adequate lubrication. }\end{array}$ \\
\hline $\begin{array}{l}\text { In case of rupture, the condom must be } \\
\text { immediately replaced. }\end{array}$ & $\begin{array}{l}\text { Press and introduce the movable ring of the } \\
\text { condom into the vagina. Using the index finger, } \\
\text { pull it as deep as possible to reach the cervix; } \\
\text { the fixed (external) ring must be around three } \\
\text { centimeters out of the vagina. During penetration, } \\
\text { guide the penis to the center of the outer ring. }\end{array}$ & Use of oily lubricants. \\
\hline $\begin{array}{l}\text { After ejaculation, take the penis out, still erect, } \\
\text { holding the base of the condom, so there is no } \\
\text { sperm leaking. }\end{array}$ & $\begin{array}{l}\text { A new condom must be used for each new } \\
\text { relation. }\end{array}$ & $\begin{array}{l}\text { Air and lack of space for taking the sperm in the } \\
\text { edge of the condom. }\end{array}$ \\
\hline \multirow{6}{*}{$\begin{array}{l}\text { The condom cannot be reused, and it must be } \\
\text { dismissed in the trash (not in the toilet seat) after } \\
\text { use. }\end{array}$} & & Improper size for the penis. \\
\hline & & Erection loss during sexual intercourse. \\
\hline & & $\begin{array}{l}\text { Contraction of the vaginal musculature while } \\
\text { taking the penis out. }\end{array}$ \\
\hline & & $\begin{array}{l}\text { Pulling the penis out without holding the base of } \\
\text { the condom firmly. }\end{array}$ \\
\hline & & Use of two condoms (due to friction between them). \\
\hline & & Use of the same condom during long intercourse. \\
\hline
\end{tabular}

FIGURE 4: Use and adequate conservation of male and female condom. 


\section{ACKNOWLEDGMENTS}

The authors acknowledge the substantial contribution of this article by the technical group of specialists responsible for developing the Clinical Protocol and Therapeutic Guidelines for Comprehensive Care (PDCT) for People with Sexually Transmitted Infections (STI) 2020.

\section{ORCID}

Maria Alix Leite Araujo - 0000-0002-4156-5783

Juliana Uesono - 0000-0001-9507-8393

Nádia Maria da Silva Machado - 0000-0001-9334-9305

Valdir Monteiro Pinto - 0000-0002-6880-7607

Eliana Amaral - 0000-0001-9151-3108

\section{AUTHORS' CONTRIBUTIONS}

Araujo MAL, Uesono J, Machado NMS, Pinto VM, and Amaral E contributed to the article's conception and design, analysis, interpretation of data, and writing the first version of the manuscript. All authors approved the final version of the paper, and are responsible for all aspects, including the assurance of accuracy and integrity.

\section{REFERENCES}

1. Ministério da Saúde (BR). Secretaria de Vigilância em Saúde. Departamento de Doenças de Condições Crônicas e Infecções Sexualmente Transmissíveis. Procolo clínico e diretrizes terapeuticas para atenção integral às pessoas com infecções sexualmente transmissíveis (IST) [Internet]. Brasília: Ministério da Saúde; 2020 [cited 2020 Oct 29]. 248 p. Available from: http://www.aids.gov.br/ptbr/pub/2015/protocolo-clinico-e-diretrizes-terapeuticas-para-atencaointegral-pessoas-com-infeccoes

2. Ministério da Saúde (BR). Secretaria de Vigilância em Saúde. Departamento de Doenças de Condições Crônicas e Infecções Sexualmente Transmissíveis. Protocolo clínico e diretrizes terapêuticas para manejo da infecção pelo HIV em adultos [Internet]. Brasília: Ministério da Saúde; 2018 [cited 2020 Oct 29]. Available from: http:// www.aids.gov.br/pt-br/pub/2013/protocolo-clinico-e-diretrizesterapeuticas-para-manejo-da-infeccao-pelo-hiv-em-adultos

3. Brasil. Ministério da Saúde. Portaria MS/GM no 42, de 5 de outubro de 2018. Torna pública a decisão de aprovar o Protocolo Clínico e Diretrizes Terapêuticas para Atenção Integral às Pessoas com Infecções Sexualmente Transmissíveis (IST) no âmbito do Sistema Único de Saúde - SUS [Internet]. Diário Oficial da União, Brasília (DF), 2018 out 8 [cited 2020 Oct 29];Seção 1:88. Available from: http://conitec.gov.br/ images/Protocolos/PCDT_DoencaChagas.pdf

4. Ministério da Saúde (BR). Secretaria de Atenção à Saúde. Departamento de Atenção Básica. Saúde sexual e reprodutiva [Internet]. Brasília: Ministério da Saúde; 2013 [cited 2020 Oct 29]. 300 p. (Cadernos de Atenção Básica, n. 26). Available from: https://bvsms.saude.gov.br/bvs/ publicacoes/saude_sexual_saude_reprodutiva.pdf

5. Naciones Unidas - ONU. Informe de la Conferencia Internacional sobre la población y el desarrollo: el Cairo, 5 a 13 de septiembre de 1994 [Internet]. Nueva York: Naciones Unidas, 1995 [cited 2020 Oct 7]. Available from: https://www.unfpa.org/sites/default/files/pub-pdf/icpd_spa.pdf
6. Coleman E. What is sexual health? Articulating a sexual health approach to HIV prevention for men who have sex with men. AIDS Behav [Internet]. 2011 Apr [cited 2020 Oct 29];15(Suppl. 1): S18-24. Available from: https://doi.org/10.1007/s10461-011-9909-y

7. World Health Organization - WHO. Defining sexual health: report of a technical consultation on sexual health [Internet]. Geneva: WHO; 2006 [cited 2020 Oct 29]. 35 p. Available from: https://www.who.int/ reproductivehealth/publications/sexual_health/defining_sexual_health.pdf

8. Creusa T, Negreiros M. Sexualidade e gênero no envelhecimento. Alceu [Internet]. 2004 jul-dez [cited 2020 Oct 29];5(9):77-86. Available at http://revistaalceu-acervo.com.puc-rio.br/media/alceu_n9 negreiros.pdf

9. Wei $\mathrm{D}, \mathrm{Xu} \mathrm{A}, \mathrm{Wu} \mathrm{X}$. The mediating effect of trust on the relationship between doctor-patient communication and patients' risk perception during treatment. Psych J [Internet]. 2020;9(3):383-91. Available from: https://doi.org/10.1002/pchj.327

10. Rocha AFB, Araújo MAL, Miranda AE, Leon RGP, Silva Junior GB, Vasconcelos LDPG. Management of sexual partners of pregnant women with syphilis in northeastern Brazil - a qualitative study. BMC Health Serv Res [Internet]. 2019 Jan [cited 2020 Oct 29];19(1):65. Available from: https://doi.org/10.1186/s12913-019-3910-y

11. Carrió FB. Entrevista clínica: habilidades de comunicação para profissionais de saúde. Porto Alegre: Artmed; 2012. 346 p.

12. Toskin I, Bakunina N, Gerbase AC, Blondeel K, Stephenson R, Baggaley $\mathrm{R}$, et al. A combination approach of behavioural and biomedical interventions for prevention of sexually transmitted infections. Bull World Health Organ [Internet]. 2020;98(6):431-4. Available from: http://dx.doi.org/10.2471/BLT.19.238170

13. Kee JWY, Khoo HS, Lim I, Koh MYH. Communication skills in patientdoctor interactions: learning from patient complaints. Health Prof Educ [Internet]. 2018 Jun [cited 2020 Oct 29];4(2):97-106. Available from: https://doi.org/10.1016/j.hpe.2017.03.006

14. Machado FSN, Carvalho MAP, Mataresi A, Mendonça ET, Cardoso LM, Yogi MS, et al. Use of telemedicine technology as a strategy to promote health care of riverside communities in the Amazon: experience with interdisciplinary work, integrating NHS guidelines. Ciênc Saúde Coletiva [Internet]. 2010;15(1):247-54. Available from: https://doi.org/10.1590/S1413-81232010000100030

15. Conselho Federal de Medicina (BR). Resolução CFM n 2.228/2019. Revoga a Resolução CFM n ${ }^{\circ} 2.227$ e reestabelece a Resolução CFM n ${ }^{\circ}$ $1.643 / 2002$, que define e disciplina a prestação de serviços através da Telemedicina [Internet]. Diário Oficial da União, Brasília (DF), 2019 mar 6 [cited 2020 Oct 29];Seção I:91. Available from: https://www.in.gov.br/ materia/-/asset_publisher/Kujrw0TZC2Mb/content/id/65864894

16. Organização Pan-Americana da Saúde - OPAS. Organização Mundial da Saúde - OMS. Saúde e sexualidade de adolescentes. Construindo equidade no SUS. [Internet]. Brasília: Ministério da Saúde; 2017 [cited 2020 Oct 29]. 71 p. Available from: http://portalarquivos.saude.gov.br/ images/PDF/2017/maio/05/LIVRO-SAUDE-ADOLESCENTES.PDF

17. Ministério do Planejamento, Desenvolvimento e Gestão (BR). Instituto Brasileiro de Geografia e Estatística - IBGE. Pesquisa nacional de saúde do escolar 2015 [Internet]. Rio de Janeiro: IBGE; 2016 [cited 2020 Oct 29]. 132 p. Available from: https://biblioteca.ibge.gov.br/visualizacao/ livros/liv97870.pdf

18. Ministério da Saúde (BR). Secretaria de Vigilância em Saúde. Departamento de Doenças de Condições Crônicas e Infecções Sexualmente Transmissíveis. Protocolo clínico e diretrizes terapêuticas para prevenção da transmissão vertical de HIV, sífilis e hepatites virais [Internet]. Brasília: Ministério da Saúde; 2019 [cited 2020 Oct 29]. 248 p. Available from: http://www.aids.gov.br/pt-br/pub/2015/protocoloclinico-e-diretrizes-terapeuticas-para-prevencao-da-transmissaovertical-de-hiv 
19. Sociedade Brasileira de Pediatria - SBP. Departamento Científico de Adolescência. Consulta do adolescente: abordagem clínica, orientações éticas e legais como instrumentos ao pediatra: manual de orientação [Internet]. Rio de Janeiro: SBP; 2019 [cited 2020 Oct 29]. Available from: https://www. sbp.com.br/fileadmin/user_upload/21512c-MO - ConsultaAdolescente abordClinica_orientEticas.pdf

20. Ministério da Saúde (BR). Secretaria de Vigilância em Saúde. Departamento de Doenças de Condições Crônicas e Infecções Sexualmente Transmissíveis. HIV/Aids | 2019. Bol Epidemiol [Internet]. 2019 Dec [cited 2020 Oct 29]; especial. Available from: http://www.aids. gov.br/pt-br/pub/2019/boletim-epidemiologico-de-hivaids-2019

21. Ministério da Saúde (BR). Secretaria de Vigilância em Saúde. Departamento de Doenças de Condições Crônicas e Infecções Sexualmente Transmissíveis. Sífilis | 2019. 2019 Oct [cited 2020 Oct 29]; especial. Available from: http://www.aids.gov.br/pt-br/pub/2019/ boletim-epidemiologico-sifilis-2019

22. Aguiar RB, Leal MCC, Marques APO. Knowledge and attitudes about sexuality in the elderly with HIV. Ciênc Saúde Coletiva [Internet]. 2020 [cited 2020 Oct 29];25(6):2051-62. Available from: https://doi. org.10.1590/1413-81232020256.18432018

23. Ministério da Saúde (BR). Nota Técnica no 04, de 3 de abril de 2017. O direito de adolescentes serem atendidos nas UBS desacompanhados dos pais ou responsáveis e as ocasiões em que é necessária a presença de pais ou responsável. [Internet]. Brasília: Ministério da Saúde; 2017 [cited 2020 Oct 29]. Available from: https://central3.to.gov.br/arquivo/494626/

24. Gérvas J, Fernández MP. Uso y abuso del poder médico para definir enfermedad y factor de riesgo, en relación con la prevención cuaternaria. Gac Sanit [Internet]. 2006 Dec [cited 2020 Oct 29];20(Suppl. 3):66-71. Available from: https://doi.org/10.1157/13101092

25. Tiplica GS, Radcliffe K, Evans C, Gomberg M, Nandwani R, Rafila A, et al. 2015 European guidelines for the management of partners of persons with sexually transmitted infections. J Eur Acad Dermatol Venereol [Internet]. 2015 [cited 2020 Oct 29];29(7):1251-7. Available from: https://doi.org/10.1111/jdv.13181

26. Wiesenfeld HC, Hillier SL, Meyn LA, Amortegui AJ, Sweet RL. Subclinical pelvic inflammatory disease and infertility. Obstet Gynecol [Internet]. 2012 Jul [cited 2020 Oct 29];120(1):37-43. Available from: https://doi.org/10.1097/aog.0b013e31825a6bc9

27. Pinto VM, Szwarcwald CL, Baroni C, Stringari LL, Inocencio LA, Miranda AE. Chlamydia trachomatis prevalence and risk behaviors in parturient women aged 15 to 24 in Brazil. Sex Transm Dis [Internet]. 2011 Oct [cited 2020 Oct 29];38(10):957-61. Available from: https://doi. org/10.1097/olq.0b013e31822037fc

28. Ministério da Saúde (BR). Secretaria de Vigilância em Saúde. Departamento de Vigilância, Prevenção e Controle das Infecções Sexualmente Transmissíveis, do HIV/Aids e das Hepatites Virais. Prevenção combinada do HIV: bases conceituais para profissionais, trabalhadores(as) e gestores(as) de saúde [Internet]. Brasília: Ministério da Saúde; 2017 [cited 2020 Oct 29]. 123 p. Available from: http:// www.aids.gov.br/pt-br/pub/2017/prevencao-combinada-do-hiv-basesconceituais-para-profissionais-trabalhadoresas-e-gestores

29. Gomes VLO, Fonseca ADF, Jundi MG, Severo TP. Percepções de casais heterossexuais acerca do uso da camisinha feminina. Esc Anna Nery [Internet]. 2011 Jan-Mar [cited 2020 Oct 20];15(1)22-30. Available from: https://doi.org/10.1590/S1414-81452011000100004

30. Nusbaum MRH, Hamilton CD. The proactive sexual health history. Am Fam Physician [Internet]. 2002 Nov [cited 2020 Oct 29];66(9):1705-12. Available from: https://www.aafp.org/afp/2002/1101/p1705.html

31. Workowski KA, Bolan GA. Sexually Transmitted Diseases Treatment Guidelines, 2015. MMWR Morb Mortal Wkly Rep [Internet]. 2015 Jun [cited 2020 Oct 29]; 64(RR3);1-137. Available from: https://www.cdc. gov/mmwr/preview/mmwrhtml/rr6403al.htm 